\title{
Conflicts between humans and crocodilians in urban areas across Brazil: a new approach to support management and conservation
}

\author{
Paulo Braga Mascarenhas-Junior ${ }^{1,9 *}$, Fábio Maffei ${ }^{2,9}$, Fábio Muniz ${ }^{3,9}$, \\ Ricardo F. Freitas-Filho ${ }^{4,5}$, Thiago Costa Gonçalves Portelinha ${ }^{6,9}$, \\ Zilca Campos ${ }^{7,9}$ and Luís A. B. Bassetti ${ }^{8,9}$
}

\begin{abstract}
Crocodilian-human conflicts, caused especially by urban expansion and habitat destruction, have been considered one of the main threats to the conservation of these species worldwide. In Brazil, such conflicts have been documented with crocodilian species all over the country. This study identified 400 conflict events in on-line journalistic news between humans and caimans within Brazilian cities between 2016 and 2021. Caiman latirostris (57.3\%) was the most common species found in large urban centers in the Northeastern and Southeastern regions. Most encounters in which the date was informed were registered in the wet season $(64.5 \%)$, and the rescues were mainly carried out by the environmental military police and fire brigades. We outlined management protocols to be undertaken by environmental agencies during crocodilian rescues to minimize animal stress and risk of accidents. The increasingly common interaction between humans and caimans in urban environments is an important alert to envisage best conducts for the coexistence between people and caimans in Brazil and shows the need to invest in public policies to mitigate the negative effects of urbanization on wildlife.
\end{abstract}

Keywords: Caimans; Habitat loss; Journalistic news; Fauna rescue, Urbanization.

1 Programa de Pós-Graduação em Biologia Animal, Universidade Federal de Pernambuco, Av. Prof. Moraes Rego, 1235 - Cidade Universitária, Recife - PE, 50670-901, Brazil.

2 Universidade Estadual Paulista, Faculdade de Ciências, Departamento de Ciências Biológicas, Bauru - SP, 17033-360, Brazil. 3 Universidade Federal do Amazonas, Departamento de Genética, Manaus - AM, 69077-000, Brazil. 4 Instituto Jacaré Conservação e Manejo de Fauna Silvestre Ltda., Rua Caçu 150, D, C62, Rio de Janeiro - RJ, 22710-074, Brazil.

5 EcoCaiman Conservação e Manejo da Biodiversidade ONG, Rua Caçu 150, D, C62, Rio de Janeiro - RJ, 22710-074, Brazil. 6 Laboratório de Caracterização de Impactos Ambientais (LCIA), Universidade Federal do Tocantins, Quadra 109 Norte, Av. NS 15, ALCNO-14, Plano Diretor Norte, Palmas - TO, 77001-090, Brazil.

7 Laboratório Vida Selvagem, Embrapa Pantanal, CP109, Corumbá, MS 79320-900, Brazil.

8 Laboratório de Ecologia Isotópica (LEI), Centro de Energia Nuclear na Agricultura/USP, Av. Centenário, 303 - Piracicaba - SP, 13400-970, Brazil.

9 Crocodylia Brasil - Grupo Brasileiro de Referência em Crocodilianos - Autoridades por Espécies e Biomas (crocodyliabrasil@gmail.com).

* Corresponding author $\bowtie$. E-mail address: PBMJ (paulobragam16@gmail.com), FM (maffei.fabio@gmail.com),

FM (fabio.lmuniz@gmail.com), RFF (institutojacare@gmail.com), TCGP (thiagoportelinha@uft.edu.br),ZC (zilca.campos@embrapa.br), LABB (luisbassetti@gmail.com) 
Part of Special Issue:

Use, Management and Conservation of Wildlife in Latin America.

Edited by Hani R. El Bizri, Melina S. Simoncini, Jair H. Castro Romero, Alejandro Meléndez Herrada, Joaquín L. Navarro.

\section{SIGNIFICANCE STATEMENT}

The main objective was to present an overview of crocodilian-human conflicts in Brazilian urban areas. The urbanization process poses a real threat to crocodilian conservation due to the destruction of its natural environment. For this reason, we created standardized management protocols to help public agents responsible for the rescues in Brazilian cities.

\section{INTRODUCTION}

Cities are expanding worldwide, and urban processes have been altering landscapes and affecting ecological, biological, and behavioral processes of biodiversity in recent decades (Angel et al. 2012; Luniak 2004). Direct impacts (e.g., habitat fragmentation) or indirect ones (e.g., contamination of water bodies) can lead to a loss of biological diversity on a local, regional, and global scale (McDonald et al. 2019), including animals of various species (Vale and Prezoto 2019). Human-wildlife coexistence is a crucial goal of conservation, and the motivation for most work on conflicts has been to protect species from anthropogenic threats (Pooley et al. 2021a). Crocodilians consist one of the most impacted groups of vertebrates by habitat overlap with humans. In Latin American and Caribbean countries, negative interactions between humans and crocodilians have increased by $39 \%$ between 2018 and 2020 (Pooley et al 2021b). This may cause fatal incidents involving humans (as documented in Colombia by Balaguera-Reina and FarfànArdia 2018 and in Mexico by García-Grajales and Buenrostro-Silva 2019), and destruction of natural sites due to greater anthropogenic activity (GonzálezDesales et al. 2021). In Brazil, several anthropogenic activities threaten crocodilian populations, such as hydroelectric dams (Campos 2015), roads (Campos et al. 2012), illegal hunting (Campos and Muniz 2019; Da Silveira and Thorbjarnarson 1999; Mendonça et al. 2016; Mourão et al. 1996; Muniz et al. 2021) and urbanization (Mascarenhas-Júnior et al. 2018). Such threats mainly affect crocodilian species locally, while the natural stocks of these species at a larger scale appear not to have been substantially impacted (Campos et al. 2019; Magnusson et al. 2019; Marioni et al. 2021; Siroski et al. 2020).

Brazilian territory has the richest diversity of crocodilian species globally, with six recognized caiman species, including several distinct new evolutionary lineages (Borges et al. 2018; Bittencourt et al. 2019; Muniz et al. 2018; Roberto et al. 2020). Exponential human growth, associated with a disorderly expansion of urban areas, has resulted in huge habitat loss, increasing the number of human conflicts (Mascarenhas-Júnior et al. 2018). In this modern scenario, new records are published regularly in the news and social media, reporting crocodilian occupation within cities and conflicts with local people, with a negative impact for both animals and humans, including pets or livestock (Basset 2016). Despite the increased number of cases reported in the last decade, this problematic situation has never been explored using rigorous scientific research (Balaguera-Reina and Farfàn-Ardia 2018).

This manuscript aims to document crocodilian occurrence in urban areas in Brazil, creating a major database based on online local news to record and map crocodilian-human interactions in all regions across the country. Due to the complete lack of knowledge of this situation in Brazil, this database will help understand the factors responsible for increasing crocodilian-human encounters. Here we evaluated information about 1) the spatial distribution of encounters between people and crocodilian species in Brazilian urban areas, 2) the seasonality of the encounters/conflicts in each region, and 3) the possible factors that explain the increase of these encounters in some Brazilian cities. Furthermore, we outlined management protocols to be undertaken by environmental agencies during crocodilian rescues to minimize animal stress and risk of accidents, supporting government environmental agencies to create better solutions that will mitigate conflicts and help improve the management and conservation of this important group of reptiles.

\section{MATERIAL AND METHODS}

To access information on human-crocodilian interactions, we extensively searched for news reporting occurence of crocodilians in urban areas at Google database, using the keywords "jacaré," "resgate," "cidade," (that means "caiman", "rescue", and "city" in Portuguese), and the name of each Brazilian state, individually in quotes. We refined the searches over the past five years (01 January 2016 to 31 May 2021) using Google's Search in "news" tab, sorting from the 
most recent to the oldest, and taking care to exclude duplicate reports of the same record. Also, we activated Google alerts between January 2020 and July 2021, adding reports that were sent to us via email, with the same criteria of keywords. To minimize bias caused by Google's algorithm, all authors carried out searches between June/2021 and July/2021 in different regions of Brazil.

For each news item, when available, we filtered information related to the date, caiman species, state, city, journal name, accident events, entity responsible for the rescue/record, and and the caiman release point or destination. Whenever possible, we also identified the seasonal period (dry or wet) based on the record date (Peel et al. 2007). In addition, to evaluate the relationship between records and season, we excluded 2021 data, which we sampled only until May, and to avoid differences between rainfall cycle across Brazilian regions. We used a chi-square test to evaluate the difference between seasons (dry and wet) and the records for each month. We considered $p<0.05$ as our level of significance.

We used journalistic news with photos or videos to confirm the species, considering Caiman latirostris, Caiman crocodilus, Caiman yacare, Paleosuchus palpebrosus, Paleosuchus trigonatus and Melanosuchus niger as naturally distributed in Brazilian territory. Species identifications in pictures were carried out by at least two authors to ensure fidelity in identification. Only records in urban areas were considered in our sample and news with two different species were considered as one journalistic news record, but two species records. Species in reports that did not have images were considered Not Assessed (N/A). We could not determine the genus in "N/A" cases because at least two genera are distributed in the regions/states where the news without photos were published.

\section{RESULTS AND DISCUSSION}

We registered all six Brazilian crocodilian species being documented as in direct contact with humans (Figure 1A), in areas with a lot of solid waste (Figure 1B), rescued in risk areas (Figure 1C), crossing roads (Figure 1D), killed by citizens (Figure 1E), and in small lakes with dense groups (Figure 1F).

We recorded 400 journalistic news, 365 on Google Search and 35 by Google Alerts, for the last five years (2016-2021) (Figure 2). Caiman latirostris was the most representative species, in $57.3 \%(\mathrm{~N}=229)$ of the total records, followed by C. crocodilus (18\%, $\mathrm{N}=72), P$. palpebrosus $(9 \%, \mathrm{~N}=36)$, M. niger $(5.5 \%, \mathrm{~N}=22), C$. yacare $(5 \%, \mathrm{~N}=20), P$. trigonatus $(3.8 \%, \mathrm{~N}=15)$, and Not Assessed (1.4\%, $\mathrm{N}=6)$. Disregarding the Google Alerts data, most reports
(37.5\%, $\mathrm{N}=137$ ) were published in 2020 (Figure 3 ), suggesting a real rising trend. Of 293 records in which date was informed, we identified that $35.5 \%$ $(\mathrm{N}=104)$ occurred in the dry season, while the majority occurred in the wet season $(64.5 \%, \mathrm{~N}=189$, $p<0.05$ ) (Table 1). Aspects of crocodilian behavior and life history may account for the variation in the rate of encounters and the number of records between species in urban environments. As an example, $C$. latirostris, which has one of the largest latitudinal distributions among crocodilians (Coutinho et al. 2013; Verdade and Piña 2007) and easily adapts to urban environments (Freitas-Filho 2008; Marques et al. 2020), had the highest number of records in our study; and P. trigonatus, whose behavior is cryptic (Magnusson and Lima 1991), was the least recorded. Furthermore, crocodilians' behavioral patterns are often characterized by seasonality. Dry periods can reduce the movement of caimans due to reduced availability of territory and food (Campos et al. 2006). With the onset of the wet season, they start to disperse, searching for resources. In urban environments, rescues are mostly observed in flood periods, when water bodies are connected to floodplain areas (Negromonte et al. 2021), or channels (natural or artificial) connected to the urban drainage system (Oliveira et al. 2021), places often overlapped by roads, houses, and other buildings.

In the past two decades, the massive access to smartphones has made it possible to record wildlife, especially in urban centers (Teacher et al. 2013; Olson et al. 2014). Furthermore, the publication of records on social media has aroused the interest of the national media and websites that end up replicating these findings. Our data showed a yearly increase in news, a trend that has remained steady until the end of the study (May 2021), when in just five months, 136 events were recorded, more than $92 \%$ of the total amount reported for $2020(\mathrm{~N}=147)$. In addition to greater access to technology (e.g., smartphones and mobile Internet networks), the shutdown period during the pandemic COVID-19 contributed to reducing the use and access to streets and urban protected areas. With less people movements, the animals possibly felt safer to disperse in cities, resulting in a higher rate of encounters and records in the media (Manenti et al. 2020; Zellmer et al. 2020).

The Northeastern region of Brazil had the highest number of reports $(29 \%, \mathrm{~N}=116)$, with increased representation in the states of Pernambuco ( $\mathrm{PE} ; \mathrm{N}=36$ ) and Bahia (BA; $\mathrm{N}=22$ ). The Southeast was the next $(26.8 \%, \mathrm{~N}=107)$, led by Rio de Janeiro (RJ; $\mathrm{N}=45)$ and São Paulo (SP; $N=39$ ) states. We recorded $24.8 \%$ ( $\mathrm{N}=99)$ of the reports for the Northern region, most in the states of Amazonas (AM; $\mathrm{N}=33$ ), Tocantins (TO; $\mathrm{N}=22$ ), and Pará (PA; $\mathrm{N}=20)$. 


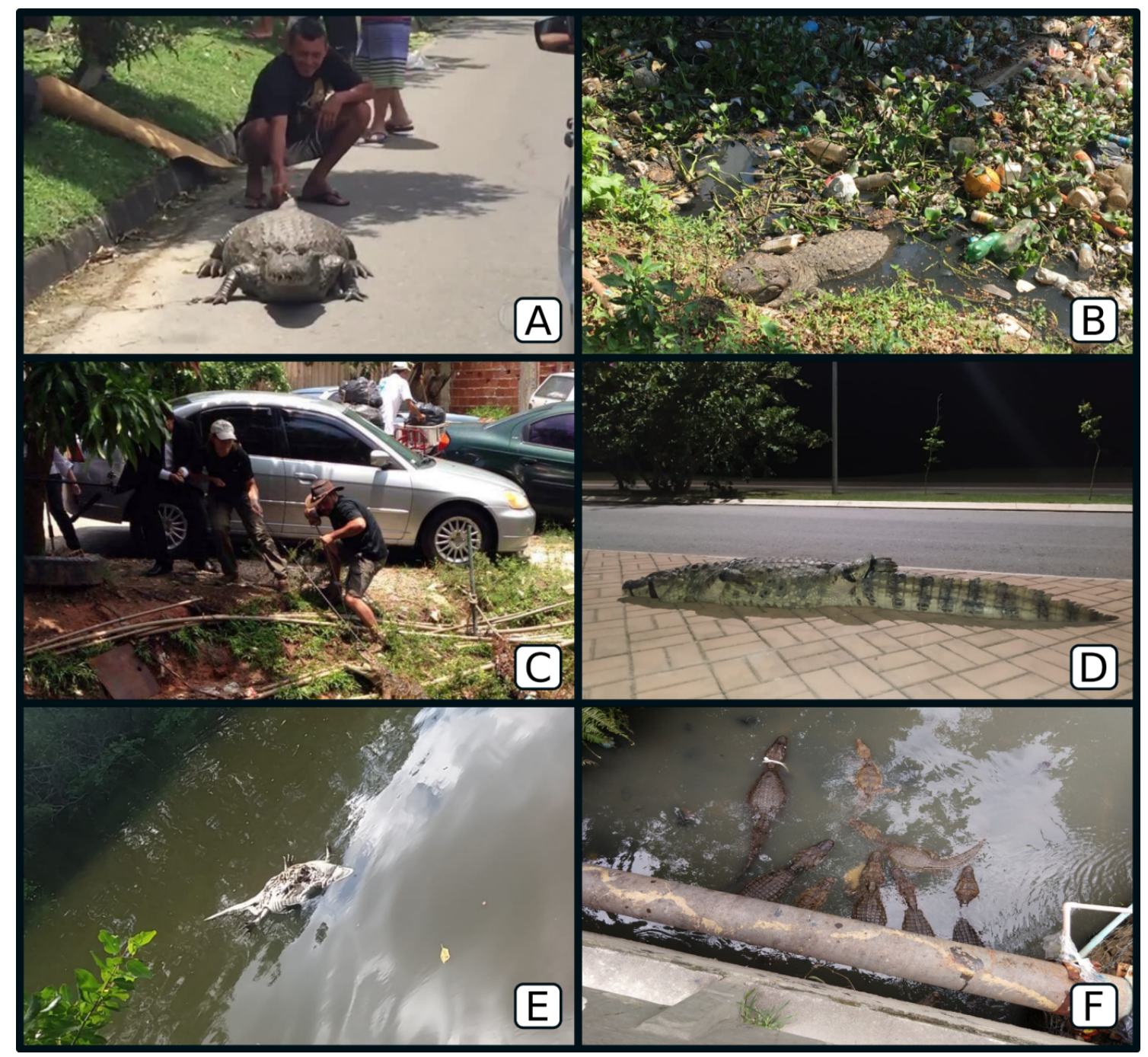

Figure 1. Caiman latirostris species in urban areas. A: direct contact with humans; B: in areas with a lot of solid waste; C: rescued by researchers at neighborhoods; D: crossing roads; E: killed by citizens; F: in small lakes with dense groups.

Table 1. Percentage of journalistic news recording caimans in urban areas in different regions of Brazil during wet and dry seasons between January 2016 and May 2021. MW: Midwest; N: North; NE: Northeast; S: South; SE: Southeast.

\begin{tabular}{|c|c|c|c|c|c|c|c|c|c|c|}
\hline \multirow{2}{*}{ Species } & \multicolumn{2}{|c|}{$\overline{M W}$} & \multicolumn{2}{|c|}{$\overline{\mathbf{N}}$} & \multicolumn{2}{|c|}{$\overline{\mathrm{NE}}$} & \multicolumn{2}{|c|}{$\overline{\mathbf{S}}$} & \multicolumn{2}{|c|}{$\overline{\text { SE }}$} \\
\hline & Wet & Dry & Wet & Dry & Wet & Dry & Wet & Dry & Wet & Dry \\
\hline Caiman crocodilus & $85.7 \%$ & $14.3 \%$ & $70 \%$ & $30 \%$ & $47.4 \%$ & $52.6 \%$ & - & - & - & - \\
\hline Caiman latirostris & $38.5 \%$ & $61.5 \%$ & - & - & $57.8 \%$ & $42.2 \%$ & $100 \%$ & 0 & $65.8 \%$ & $34.2 \%$ \\
\hline Caiman yacare & $70 \%$ & $30 \%$ & - & - & - & - & - & - & - & - \\
\hline Melanosuchus niger & - & - & $65 \%$ & $35 \%$ & - & - & - & - & - & - \\
\hline Paleosuchus palpebrosus & $87.5 \%$ & $12.5 \%$ & $70.6 \%$ & $29.4 \%$ & $58.3 \%$ & $41.7 \%$ & - & - & - & - \\
\hline Paleosuchus trigonatus & $100 \%$ & $0 \%$ & $83.3 \%$ & $16.7 \%$ & - & - & - & - & - & - \\
\hline Not Accessed & $100 \%$ & $0 \%$ & $100 \%$ & $0 \%$ & $0 \%$ & $100 \%$ & - & - & - & - \\
\hline
\end{tabular}

On the other hand, the Midwestern region (13.3\%, $\mathrm{N}=54$ ) was represented mainly by the states of Mato Grosso do Sul (MS; N = 28) and Mato Grosso (MT;
$\mathrm{N}=11$ ). Finally, the Southern region (6.1\%), was represented primarily by the states of Santa Catarina $(\mathrm{SC} ; \mathrm{N}=12)$ and Rio Grande do Sul (RS; N =7) 


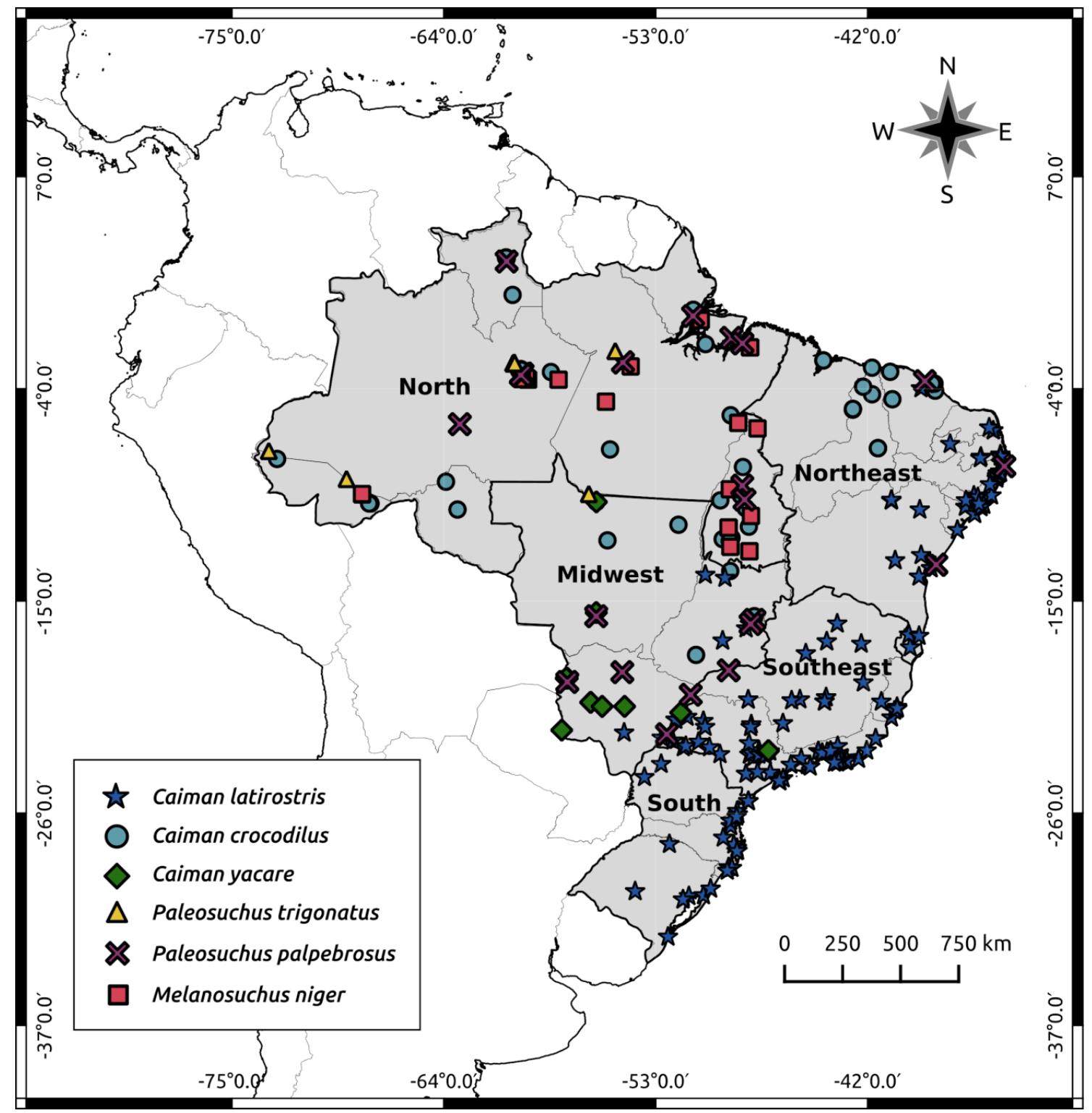

Figure 2. Spatial distribution for human-caiman encounters recorded on digital media between 2016

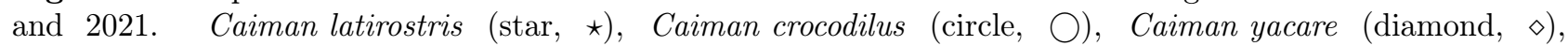
Paleosuchus trigonatus (triangle, $\triangle$ ), Paleosuchus palpebrosus (cross, $\times$ ), and Melanosuchus niger (square, ).

(Figure 4; Additional File 1).

In the Northeast of Brazil, there are many landscapes changes and natural environment destruction in large cities, mainly in state capitals and neighboring cities, where caimans were most registered. More than $90 \%$ of the original Atlantic Rainforest has been lost to deforestation and urban expansion (Lôbo et al. 2011), increasing the human-crocodilian conflict by reducing caimans' habitats. The high rate of $C$. latirostris records reflects this overlap, given it is a well-distributed species in this forest domain and in urban areas in northeastern Brazil (Mascarenhas-Júnior et al. 2018; Siroski et al. 2020). This degradation scenario also occurs in other large cities or metropolitan regions, such as Fortaleza (CE), Teresina (PI), and São Luís (MA; Silva et al. 2019), with a higher frequency of $C$. crocodilus.

The Northeastern region has a marked hydrological cycle with limited rainfall (up to five months) and perennial rivers (Rebouças 1997). In the Recife (PE) metropolitan region, the branched water network offers habitats and conditions for the establishment of caimans' populations (Mascarenhas-Júnior et al. 2018). In addition, destruction of the riparian forest exposes water bodies to roads or houses, which facilitates specimens' dispersion, and increases solid waste into the water systems (Bezerra et al. 2018). In Salvador (BA), the fourth largest city in Brazil, 
and the main economic center in the Northeast, urbanization has been illegally occupying natural areas (Souza 2001) and weakening urban natural ecosystems (Machado et al. 2019). Soil and river contamination (Moura et al. 2010), as well as local temperature, changes due to vegetation suppression (Correia-Filho et al. 2019), which can directly affect the biological cycles of urban species, mainly crocodilians, considering they are ectothermic and potential top predators in aquatic environments (Somaweera et al. 2020).

In Rio de Janeiro state, the recent expansion of large cities has caused the destruction of local landscapes and natural environments (such as restingas [sandbars or shoals], mangroves, and the Atlantic

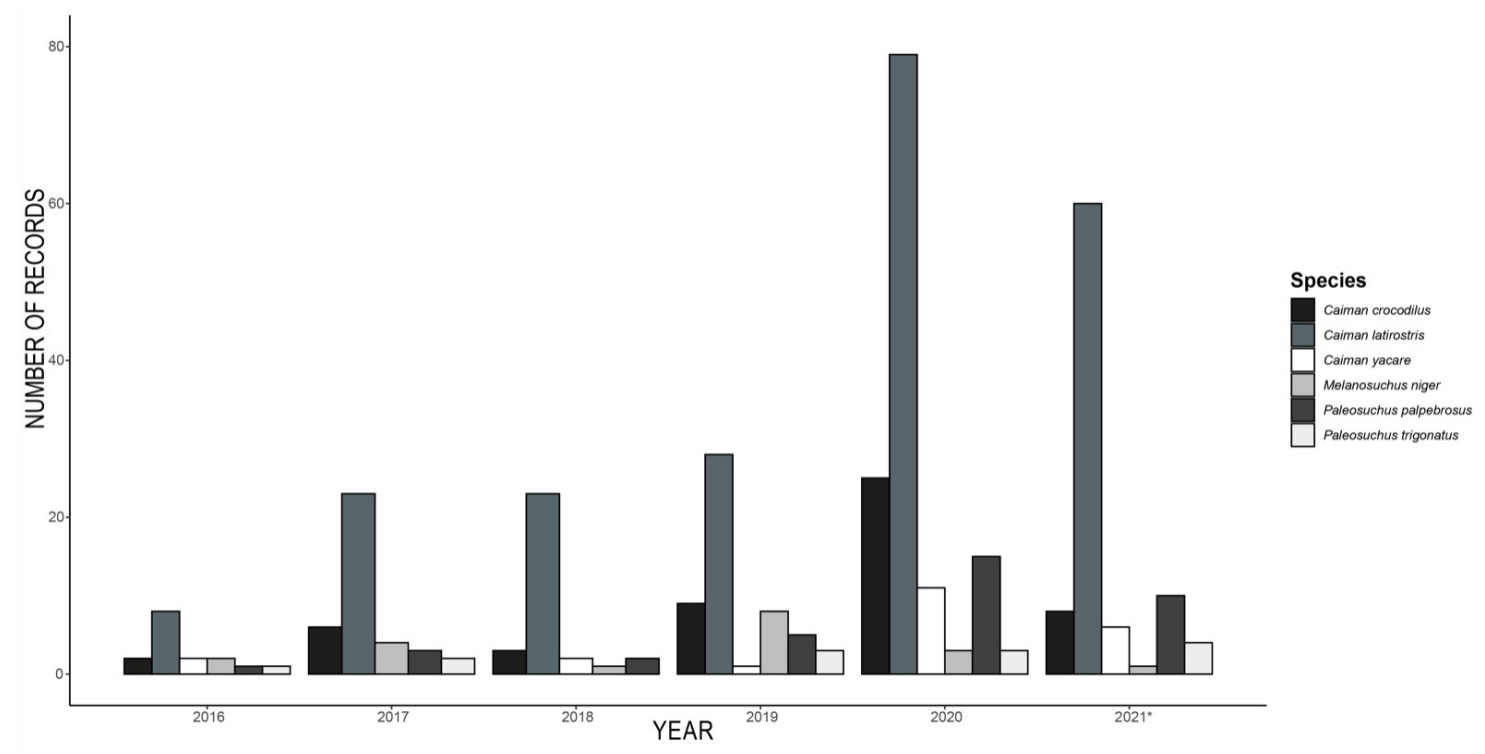

Figure 3. Records for humans and caiman species published on digital media and tracked using Google searches between 2016 and 2021 in Brazil.

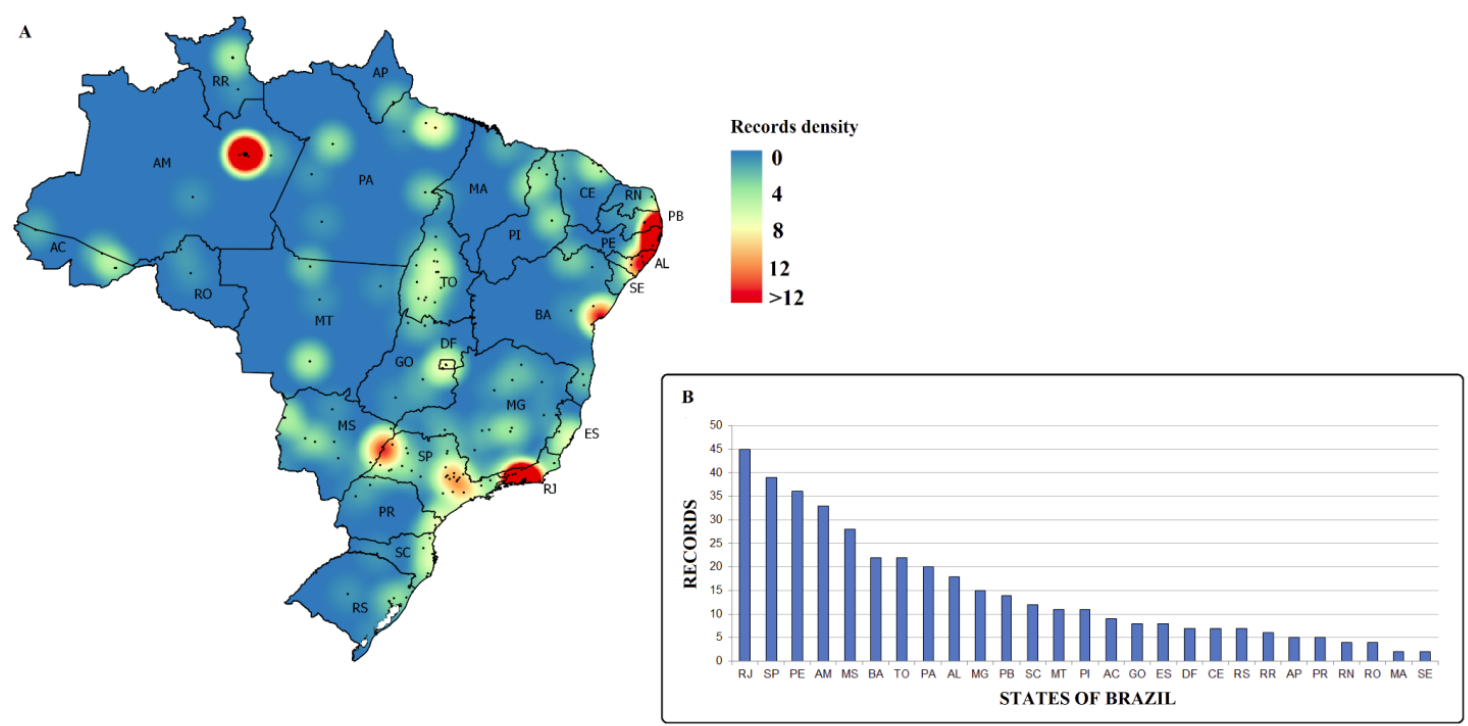

Figure 4. Human-caimans encounters recorded in online journalistic news in Brazil, between 2016 and 2021. Brazilian state names are abbreviated by two capital letters. AC: Acre, AL: Alagoas, AM: Amazonas, AP: Amapá, BA: Bahia, CE: Ceará, DF: Distrito Federal, ES: Espírito Santo, GO: Goiás, MA: Maranhão, MG: Minas Gerais, MT: Mato Grosso, MS: Mato Grosso do Sul, PA: Pará, PB: Paraíba, PE: Pernambuco, PI: Piauí, PR: Paraná, RJ: Rio de Janeiro, RN: Rio Grande do Norte, RO: Rondônia, RR: Roraima, RS: Rio Grande do Sul, SE: Sergipe, SC: Santa Catarina, SP: São Paulo, TO: Tocantins. 
Rainforest; Díez and Montezuma 2021), which led to an increase in the occurrence of animals in urban areas. One of the most altered landscapes in Rio de Janeiro is the Lagoon Complex of Jacarepaguá, a well-known area for wild C. latirostris populations (Freitas-Filho 2008). Since 2010, mainly because of the choice of Rio de Janeiro as the host city of the Soccer World Cup and 2016 Olympic Games, many natural environments have been occupied (Lopes et al. 2014; Peres et al. 2018) and wetlands backfilled, drastically changing the flooded areas used by caimans. During dispersion in the search for new territories, several caimans are found in sewer channels or rescued on highways and houses (Freitas-Filho et al. 2013).

It is estimated that more than $70 \%$ of the Brazilian human population lives in regions covered by the Atlantic Rainforest, with more than 145 million people inhabiting 3,429 municipalities, which represents $61 \%$ of Brazilian cities (SOSMA 2021). Fragmentation of the biome for urban expansion limits access to essential resources for crocodilians, such as food, territory, and nesting areas (López-Luna et al. 2011). With the lack or scarcity of these resources, animals tend to disperse to new habitats, often seeking food offered by humans, creating a behavior of proximity and conditioning the caimans to settle in these areas waiting for food (Freitas-Filho et al. 2009). In addition, cities with many rivers, which create a branched water network, sewage systems and rainwater channels, facilitates the movement of caimans in urban environments, favoring their appearance in risk areas (Mascarenhas-Júnior et al. 2018).

Most of encounters in the Midwest region occurred between $C$. latirostris and people $(\mathrm{N}=12)$ who frequented a downtown natural lake in Três Lagoas city in the state of Mato Grosso do Sul. Individuals of $C$. latirostris can easily be spotted basking or walking on the running track that surrounds the lagoon, resulting in several encounters with people. In two events, four C. latirostris males (snout-vent length - SVL > $90 \mathrm{~cm}$ ) were removed from Lagoa Maior lake and released carrying radio transmitters in the Reserva Particular do Patrimônio Natural-RPPN Cisalpina (Campos, pers.com.). The entire rescue and translocation operation was carried out by the Municipal Environmental Secretariat, under the guidance of specialists, led by Zilca Campos, who also provided advice on measures to ensure safe interaction between animals and the people who use the area around the Lagoa Maior.

One of our records indicates that species introduced outside their natural occurrence area still maintain their populations in urban centers, such as C. yacare, reported in the municipality of Paulínia (SP), about $500 \mathrm{~km}$ away from its distribution (Campos et al. 2020). Initially, these animals were in- troduced into the state of São Paulo in the 1980s, with authorization from the national environmental agency, IBAMA (Instituto Brasileiro do Meio Ambiente e dos Recursos Renováveis), which allowed the installation of commercial breeding sites outside the occurrence area of the species. Most of these projects were abandoned, resulting in an incalculable number of releases in natural water bodies (Verdade 2004). The introduction of exotic or allochthonous species can be potentially harmful to ecosystems, and the presence of crocodilians outside their natural range is harmful to native species (Verdade 2004; Da Silveira et al. 2020). Introductions of $C$. crocodilus with established populations in South Florida, USA (Ellis 1980), and the escape of Crocodylus moreletii to the west coast of Mexico (Rodriguez et al. 2008), have been documented, potentially causing irreparable damage to local species and habitats.

The Northern and the Midwestern regions are home to the most remarkable crocodilian diversity in the country (five species), but this is not necessarily related to the higher number of human-crocodilian encounters in Brazil. Despite a high rate of urbanization, it still contains many legal protected areas around urban centers (Silva et al. 2017). According to our data, a large Black Caiman (M. niger) caused one fatal accident in a city in the state of Tocantins. Although uncommon, accidents involving this species have already been reported for the Brazilian Amazon (Bergamasco et al. 2018; Haddad-Júnior and Fonseca 2011; Marioni et al. 2013). It is noteworthy that this is the largest caiman species in the Brazilian territory (Thorbjarnarson 2010), and some of its attacks can be deadly. In the case mentioned above, the urban population killed the Black Caiman in retaliation for the incident, a practice reported for some countries in Latin America and the Caribbean (Pooley et al. 2021b). Over the past 20 years, Brazil has led the ranking of cases involving fatal crocodilian attacks in South America, with M. niger responsible for most of them (Pooley et al. 2021b). Those negative interactions can lead to aggressive measures from the population, such as nest destruction and crocodilian killings (Pooley 2020; Pooley et al. 2021a), even in situations of low risk and involving smaller species, such as species within the Caiman and Paleosuchus genera. The concern about M. niger occurrences in urban areas needs to be highlighted, as individuals can reach a total length of 6 meters (Medem 1983), thus representing a greater risk of fatal accidents. In addition, it is essential to emphasize that state capitals had a higher frequency of records within urban areas. Manaus is the city with the most reports $(\mathrm{N}=28$, $7 \%$ from Black Caiman), three times more cases than Belém ( $\mathrm{N}=9,33 \%$ from Black Caiman), the second city in the North with the highest number of occur- 
rences. The high number of records from Manaus may be explained by the marked urbanization process, associated with uncontrolled growth towards the preserved environments in the outskirts, the abundance of water bodies, and the forest fragments inside the city.

Crocodilian rescues were reported in $84 \%$ of journalistic news $(\mathrm{N}=336)$. Most procedures were carried out by public agencies, such as fire brigades $(\mathrm{N}=124)$, police (military or civilian; $\mathrm{N}=119$ ), and municipal environmental brigades $(\mathrm{N}=38)$. On the other hand, 62 rescues (involving capture and handling) were carried out by the population and 57 by other fauna agencies that eventually helps in these procedures (e.g., Municipal Environmental Secretariats, Zoos, and Civil Defense). In Brazil, wildlife management must be carried out by authorized persons or organizations (private or public), even in urban areas. Until 2014, wildlife rescue demands in urban centers were conducted mainly by the IBAMA, environmental military police, and fire brigades (MascarenhasJúnior et al. 2018; Teixeira et al. 2016). Recently, as of the enactment of Complementary Law 140/2011 (Brazil 2011), fauna management has been decentralized, with the competence devolving upon each Brazilian state and/or city. Those idiosyncratic conditions lead to a lack of standardization in rescues, making it difficult for the population to know the most appropriate communication channel for help. Therefore, we recommend that environmental organizations or fauna rescue agencies should be the first to be contacted during risk situations with caimans, considering that they are trained and have adequate equipment for handling the animals. A good rescue by trained people or organizations can prevent accidents, or even animal death. Moreover, researchers and groups that work directly with caimans can provide technical support when necessary, such as the Instituto Jacaré in Rio de Janeiro-RJ (Freitas-Filho et al. 2013), Projeto Caiman in Vitória-ES (Mello et al. 2019) and Projeto Jacaré in Recife-PE (MascarenhasJunior et al. 2018).

The destination of the caiman was frequently reported $(72.5 \%, \mathrm{~N}=290)$. Returning specimens to their natural environment was the primary choice $(72.4 \%, \mathrm{~N}=210)$, followed by rehabilitation and screening centers $(16.2 \%, \mathrm{~N}=47)$, even when the individual had apparently good health conditions. In 17 cases $(5.8 \%)$, caimans were relocated to other institutions (e.g., universities and zoos), but without information regarding their destination, and in 16 records $(5.6 \%)$, caimans were found dead (seven of them killed by the local population). The destination of the animals after rescue is one of the most critical steps in the entire process involving conflicts with urban crocodilians. Goulart et al. (2010) recommend that rescued animals should be sent to screening and rehabilitation centers for possible veterinary treatment and subsequent release (Teixeira et al. 2016). It is vital to collect specimen data to monitor populations during the process and determine critical points of conflict. In cases where release is possible, we recommend that caimans should be moved far from the urban center, but prioritizing the same watershed, aiming to mitigate interactions with humans and potential damage to the environment (Da Silveira et al. 2020).

One of the significant challenges of managing Brazilian fauna is standardizing protocols of rescue and destination specimens. The decentralization of environmental activities makes this demand difficult, but solutions must be sought. More and more professionals who work with crocodilians in Brazil are strengthening relationships with, sharing experiences with, and joining in representative groups from all regions, such as Crocodylia Brasil, a Brazilian Reference Group on Crocodilians - Authorities by Species and Biomes (Bassetti et al. 2021). We strongly recommend that institutions responsible for fauna management (at state and municipal levels) contact crocodilian specialists so that the best procedures are carried out regarding the management of caimans in urban environments. In this sense, we developed a proposal for a standard protocol for the proper rescue, health treatment, data collection and destination of crocodilians in urban environments (Figure 5). It is important for humans to understand that wildlife is part of daily life in cities, and rescues should only be performed if animals and/or people are at risk. Under these conditions, we suggest that people contact the fire departments, military police and guards or local environmental agencies for the proper rescue. The capture and containment procedure must be carried out by a trained team with adequate equipment, such as: locking cable snares, for capture; cloths, to cover the eyes and minimize the caiman's stress; and adhesive tapes and ropes, to close and immobilize jaws and limbs, respectively, preventing bites and abrupt movements. After the process, the caiman must be taken to rehabilitation and/or screening centers for later release in a natural water body far from the city, but in the same hydrographic basin. We also suggest taking basic biometric data (at least total and snout-vent length) and biological samples, as well as conducting scutes cut, associated with tags or microchips (when possible) to mark rescued specimens, so that they can be properly monitored. This standard protocol, allied with other local recommendations from specialists in crocodilians, is important to promote animal welfare, reduce the risk of accidents, and encourage caiman protection and conservation policies within cities. 


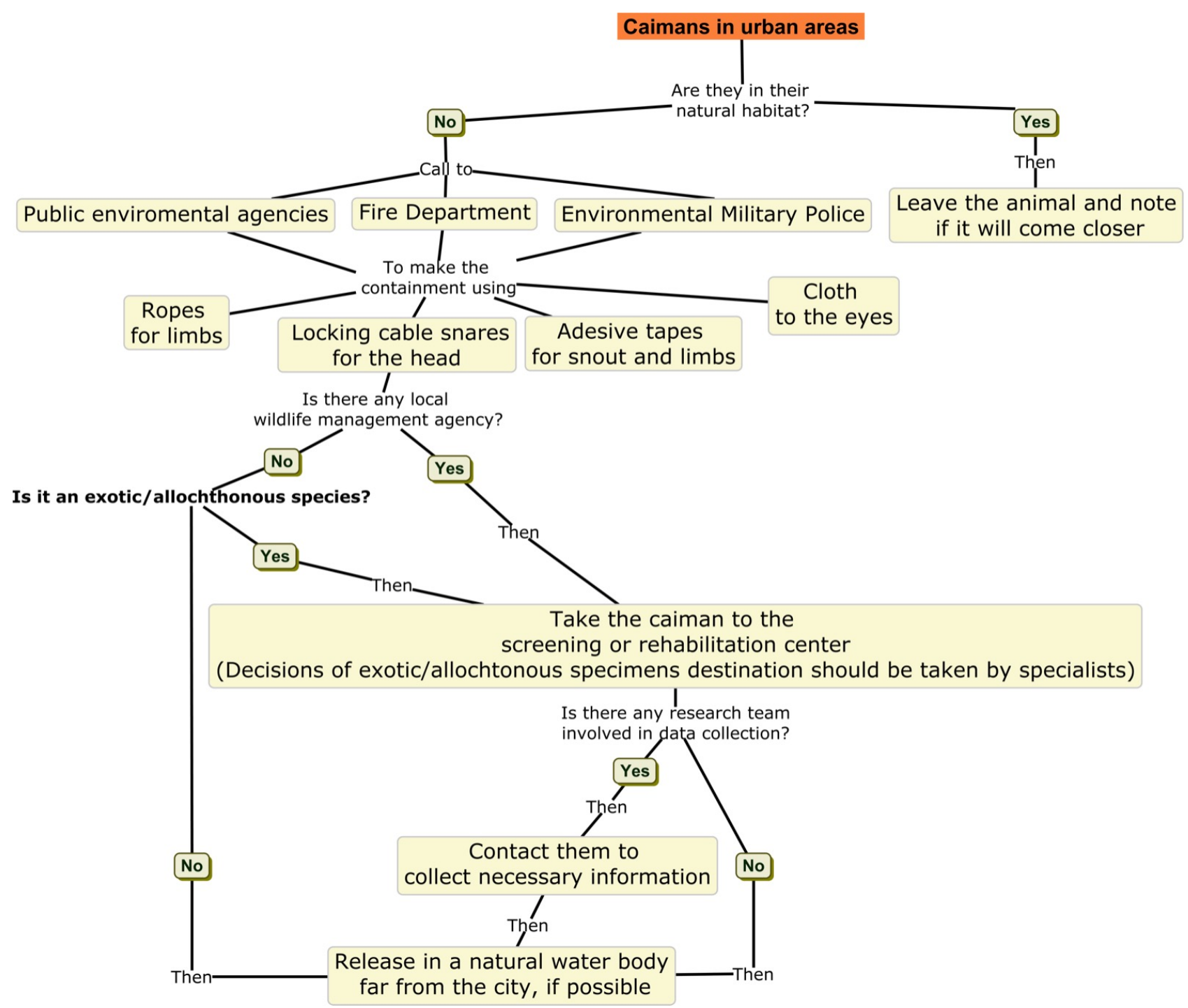

Figure 5. Flowchart of actions to be taken in rescue and translocation of crocodilians in urban areas of Brazilian cities - Training of those involved in operations to be carried out by the Municipal Environmental Secretariats.

\section{CONCLUSION}

1. Caiman latirostris was the most recorded species and had the widest distribution in Brazilian urban centers;

2. Encounters between humans and caimans have gradually increased in the last two years, which could be associated with access to technology, mobile cellular networks, and probably influenced by lockdown caused by the SARS-CoV-2 pandemic scenario;

3. Urban expansion and the environmental, behavioral, and natural history of crocodilians are possibly directly related to caiman occurrence and records in urban environments, especially in the wet season and in the Southeastern, Northeastern and parts of Northern regions of Brazil;
4. The contact between humans and caimans in urban areas can lead to conflicts, such as accidents (fatal or not) and pet deaths, leading to extreme measures by the population. Therefore, it is suggested that government agencies should consider crocodilianhuman interaction, protection strategies, and control measures in their public policies;

5. Solid strategies and standardized management protocols for crocodilians must be implemented at the national level, including public agencies that could receive technical training from research groups and experts in the field. 


\section{ACKNOWLEDGEMENT}

This publication is funded in part by the Gordon and Betty Moore Foundation through Grant No. GBMF9258 to the Comunidad de Manejo de Fauna Silvestre en la Amazonía y en Latinoamérica (COMFAUNA). Members of Crocodylia Brasil helped with information about urban caimans.

\section{DATA AVAILABILITY}

The data used to support the findings of this study are available from the corresponding author upon reasonable request.

\section{CONFLICT OF INTEREST}

The authors have no conflicts of interest to declare.

\section{CONTRIBUTION STATEMENT}

Conceived the presented idea: PBMJ, FM, LABB, ZC.

Carried out the experiment: PBMJ, FM, FM, RFF, TCGP, LABB, ZC.

Carried out data analysis: PBMJ, FM, FM, ZC. Wrote the first draft of the manuscript: PBMJ, FM, FM, RFF, TCGP, LABB, ZC.

Review and final writing of the manuscript: PBMJ, FM, FM, RFF, TCGP, LABB, ZC.

Supervision: ZC, LABB.

\section{REFERENCES}

Angel S, Blei AM, Civco DL, Parent J (2012) Atlas of Urban Expansion (Lincoln Institute of Land Policy. Lincoln Institute of Land Policy, Cambridge, MA, USA. pp. 397.

Basset LAB (2016) Estado sanitário do jacaréde-papo-amarelo (Caiman latirostris) em paisagens antropizadas no Estado de São Paulo. PhD Thesis, Universidade de São Paulo, Piracicaba, BR.

Bassetti LAB, Da Silveira R, Botero-Arias R, Campos Z, Magnusson WE, Verdade LM, Portelinha TCG, Roberto IJ, Kluczkovski-Junior A, Marioni B, Mascarenhas-Junior PB, Muniz F, Maffei F, Araújo DD, Moura EC (2021) Crocodylia Brazil Group (Crocbr): A Reference Network In The Research And Conservation Of Brazilian Crocodilians. Crocodile Specialist Group Newsletter 39: 13-14.
Balaguera-Reina SA, Farfàn-Ardila NIDIA (2018) Are we ready for successful apex predator conservation in Colombia? Human-crocodilian interactions as a study case. Herpetological review 49:5-12.

Bergamasco CJJ, Pereira RM, Rios Rodriguez JE, Fernandes Cabral BT (2018) Thoracic trauma by black caiman's bite in the Amazon region. Journal of Cardiothoracic Trauma 3:24-6.

Bezerra APXG, Gabriel FA, Lorena EMG, Santos IGS, Silva MC, Neto FCR (2018) Environmental Diagnosis of Permanent Preservation Areas (APP) of the Capibaribe River in the city of Recife-PE. Revista Geama 4:5-12.

Bittencourt PS, Campos Z, Muniz F, Marioni B, Souza BC, Da Silveira R, De Thoisy B, Hrbek T, Farias IP (2019) Evidence of cryptic lineages within a small South American crocodilian: the Schneider's dwarf caiman Paleosuchus trigonatus (Alligatoridae: Caimaninae). PeerJ 7:e6580.

Borges VS, Santiago PC, Lima NG, Coutinho ME, Eterovick PC, Carvalho DC (2018) Evolutionary significant units within populations of Neotropical broad-snouted caimans (Caiman latirostris, Daudin, 1802). Journal of Herpetology 52:282-288.

Brasil (2011) Lei Complementar no 140. Presidência da República - Casa Civil. Brasília/DF. [http://www.planalto.gov.br/ccivil_03/ leis/lcp/lcp140.htm] Accessed 13 July 2021.

Campos Z (2015) Size of caimans killed by humans at a hydroelectric dam in the Madeira River, Brazilian Amazon. Herpetozoa 28:101-104.

Campos Z, Coutinho M, Mourão G, Bayliss P, Magnusson WE (2006) Long distance movements by Caiman crocodilus yacare: implications for management of the species in the Brazilian Pantanal. The Herpetological Journal 16:123-132.

Campos Z, Llobet A, Magnusson WE, Piña C (2020) Caiman yacare (in IUCN Red List of Threatened Species 2020). IUCN. e.T46586A3009881. [https://dx.doi.org/10. 2305/IUCN.UK.2020-3.RLTS.T46586A3009881] Accessed 18 June 2021.

Campos Z, Magnusson WE, Muniz F. (2019) Paleosuchus trigonatus (in IUCN Red List of Threatened Species 2019). IUCN. e.T46588A3010035. [http://dx.doi.org/10. 2305/IUCN . UK . 2019-1. RLTS . T46588A3010035 .en] 
Accessed 20 June 2021.

Campos Z, Mourão G (1995) Caiman latirostris (Broad-snouted caiman). Nesting. Herpetological Review 26:203-204.

Campos Z, Muniz F, Magnusson WE (2012) Dead Paleosuchus on roads in Brazil. Crocodile Specialist Group Newsletter 31:12-14.

Campos Z, Muniz FL (2019) Multiple uses of Cuvier's dwarf caiman, Paleosuchus palpebrosus, in the semi-arid region of Northeastern Brazil. Crocodile Specialist Group Newsletter 38:5-9.

Correia-Filho WLF, Santiago DB, Oliveira-Júnior JF, Junior CAS (2019) Impact of urban decadal advance on land use and land cover and surface temperature in the city of Maceió, Brazil. Land Use Policy 87:104026.

Coutinho ME, Marioni B, Farias IP, Verdade LM, Bassetti LAB, Mendonça SH, Vieira TQ, Magnusson WE, Campos Z (2013) Avaliação do risco de extinção do jacaré-de-papo-amarelo Caiman latirostris (Daudin, 1802) no Brasil. Biodiversidade Brasileira-BioBrasil 1:13-20.

Da Silveira R, Botero-arias R, Marioni B, Kluczkovski-Junior A, Moura E, Maffei F, Araújo DD, Portelinha TCG, Roberto IJ, Mascarenhas-Junior PB, Muniz F, Campos Z, Magnusson WE, Verdade LM, Bassetti LAB (2020) Rearing Black Caiman (Melanosuchus Niger) outside its distribution range concerns the brazilian crocodilian research community. Crocodile Specialist Group Newsletter 39:20-22.

Da Silveira R, Thorbjarnarson JB (1999) Conservation implications of commercial hunting of black and spectacled caiman in the Mamirauá Sustainable Development Reserve, Brazil. Biological Conservation 88:103-109.

Díez MC, Montezuma RDC (2021) Edible Restinga: A Socio-Environmental Proposal Inside the Urban Landscape in the West Side of Rio de Janeiro, Rio de Janeiro-Brazil. Sociedade Es Natureza doi: 10.14393/SN-v33-2021-58037.

Ellis TM (1980) Caiman crocodilus: an established exotic in South Florida. Copeia 1980:152154 .

Freitas-Filho RF (2008) Dieta e Avaliação de Contaminação Mercurial no Jacaré-de-PapoAmarelo, Caiman latirostris, Daudin 1802, (Crocodylia, Alligatoridae) em Dois Parques Naturais no Município do Rio de Janeiro, Brasil. MSc Thesis, Federal University of Juiz de Fora, Juiz de Fora, Brazil.
Freitas-Filho RF (2013) Ecologia urbano do jacaré de papo amarelo (Caiman latirostris, Daudin 1802) no Complexo Lagunar de Jacarepaguá, Rio de Janeiro, RJ. PhD Thesis, Universidade do Estado do Rio de Janeiro, Rio de Janeiro, Brazil.

Freitas-Filho RF, Piña CI, Moulton TP (2009) "Our Hidden Enemy" and the Irrational Fear of Crocodilians. Crocodile Specialist Newsletter 28:89.

García-Grajales J, Buenrostro-Silva A (2019) Assessment of human-crocodile conflict in Mexico: patterns, trends and hotspots areas. Marine and Freshwater Research 70:708-720.

González-Desales GA, Sigler L, García-Grajales J, Charruau P, Zarco-González M M, Balbuena-Serrano A, Monroy-Vilchis O (2021) Factors influencing the occurrence of negative interactions between people and crocodilians in Mexico. Oryx doi: $10.1017 /$ S0030605319000668.

Goulart VDLR, Teixeira CP, Young RJ (2010) Analysis of callouts made relative to wild urban marmosets (Callithrix penicillata) and their implications for urban species management. European Journal of Wildlife Research doi: 10.1007/s10344-009-0362-4.

Haddad-Júnior V, Fonseca WC (2011) A fatal attack on a child by a black caiman (Melanosuchus niger). Wilderness $\&$ environmental medicine doi: 10.1016/j.wem.2010.11.010.

Lôbo D, Leão T, Melo FP, Santos AM, Tabarelli M (2011) Forest fragmentation drives Atlantic forest of northeastern Brazil to biotic homogenization. Diversity and Distributions doi: 10.1111/j.1472-4642.2010.00739.x.

Lopes LA, Oliveira MM, Soares CA (2014) The effects of the 2014 World Cup in real estate market in Rio de Janeiro and São Paulo. International Proceedings of Economics Development and Research doi: 10.7763/IPEDR.

López-luna MA, Hidalgo-mihart MG, Aguirre-león G (2011) Description of Morelet's crocodile Crocodylus moreletii nests from an urban landscape in southeastern Mexico. Acta zoológica mexicana 27:1-16.

Luniak M (2004) Synurbization-adaptation of animal wildlife to urban development. In Proceedings 4th international urban wildlife symposium (pp. 50-55). University of Arizona.

Machado RA, Oliveira AG, Lois-González RC (2019) Urban ecological infrastructure: The importance of vegetation cover in the control 
of floods and landslides in Salvador/Bahia, Brazil. Land Use Policy 89:104180.

Magnusson WE, Campos Z, Muniz F (2019) Paleosuchus palpebrosus (in IUCN RedList of Threatened Species 2019). IUCN. e.T46587A3009946. [10.2305/IUCN.UK.20191.RLTS.T46587A3009946.en] Accessed 20 June 2021.

Magnusson WE, Lima AP (1991) The ecology of a cryptic predator, Paleosuchus trigonatus, in a tropical rainforest. Journal of Herpetology 25:4148.

Manenti R, Mori E, Di Canio V, Mercurio S, Picone M, Caffi M, Brambilla M, Ficetola GF, Rubolini D (2020) The good, the bad and the ugly of COVID-19 lockdown effects on wildlife conservation: Insights from the first European locked down country. Biological conservation 249:108728.

Marioni B, Barão-Nóbrega JAL, Botero-Arias R, Muniz F, Campos Z, Da Silveira R, Magnusson WE, Villamarín F (2021) Science and conservation of Amazonian crocodilians: a historical review. Aquatic Conservation: Marine and Freshwater Ecosystems 31:1056-1067.

Marioni B, Farias I, Verdade LM, Bassetti LAB, Coutinho ME, Mendonça SH, Veira TQ, Magnusson WE, Campos Z (2013) Avaliação do risco de extinção do jacaré-açu Melanosuchus niger (Spix, 1825) no Brasil. Biodiversidade BrasileiraBioBrasil 1:31-39.

Marques TS, Bassetti LAB, Lara NR, Portelinha TC, Piña CI, Verdade LM (2020) Home Range and Movement Pattern of the Broad-Snouted Caiman (Caiman latirostris) in a Silviculture Dominated Landscape. South American Journal of Herpetology 16:16-25.

Mascarenhas-Júnior PB, Santos EM, Correia JMS (2018) Diagnóstico dos resgates de jacarés na região metropolitana do Recife, Pernambuco. Revista Ibero-Americana de Ciências Ambientais 9:138-145.

McDonald RI, Mansur AV, Ascensão F, Crossman K, Elmqvist T, Gonzalez A, Güneralp B, Haase D, Hamann M, Hillel O, Huang K, Kahnt B, Maddox D, Pacheco A, Pereira HM, Seto KC, Simkin R, Walsh B, Werner AS, Ziter C (2020) Research gaps in knowledge of the impact of urban growth on biodiversity. Nature Sustainability 3:16-24.

Medem F (1983) los crocodylia de Sur America. 2 ed. Colciencias, universidad Nacional de colombia, Bogota, pp. 259.
Mello B, Nóbrega Y, Santos M (2019) Projeto Caiman - Environmental Education. Crocodile Specialist Group Newsletter 38:15-17.

Mendonça WCDS, Marioni B, Thorbjarnarson JB, Magnusson WE, Da Silveira R (2016) Caiman hunting in central Amazonia, Brazil. The Journal of Wildlife Management 80:1497-1502.

Moura MCS, Moita GC, Neto JMM (2010) Analysis and assessment of heavy metals in urban surface soils of Teresina, Piauí State, Brazil: a study based on multivariate analysis. Comunicata Scientiae 1:120-120.

Mourão G, Campos Z, Coutinho M, Abercrombie C. (1996) Size structure of illegally harvested and surviving caiman Caiman crocodilus yacare in Pantanal, Brazil. Biological Conservation 75:261265.

Muniz F, Campos Z, Bittencourt PS, Hrbek T, Farias IP (2021) Report of poaching of dwarf caimans Paleosuchus spp. (Alligatoridae: Caimaninae) for meat consumption in northern Brazilian Amazon. Herpetology Notes 14:661-665.

Muniz F, Campos Z, Rangel SH, Martínez JG, Souza BC, De Thoisy B, Botero-Arias R, Hrbek T, Farias IP (2018) Delimitation of evolutionary units in $\mathbf{C u}-$ vier's dwarf caiman, Paleosuchus palpebrosus (Cuvier, 1807): insights from conservation of a broadly distributed species. Conservation genetics 19:599-610.

Negromonte MG, Mascarenhas-Junior, PB, Santos EM, Correia JS (2021) Resgate, apreensão e destinação da herpetofauna pelos órgãos de fauna na região metropolitana do recife, pernambuco - contribuição para conservação. Revista IberoAmericana de Ciências Ambientais 12.

Oliveira VCS, Viana PF, Gross MC, Feldberg E, Da Silveira R, Cioffi MB, Bertollo LAC, Schneider CH (2021) Looking for genetic effects of polluted anthropized environments on Caiman crocodilus crocodilus (Reptilia, Crocodylia): A comparative genotoxic and chromosomal analysis. Ecotoxicology and Environmental Safety 209:111835.

Olson DD, Bissonette JA, Cramer PC, Green AD, Davis ST, Jackson PJ, Coster DC (2014) Monitoring wildlife-vehicle collisions in the information age: how smartphones can improve data collection. PloS one 9: e98613.

Peel MC, Finlayson BL, McMahon TA (2007) Updated world map of the Köppen-Geiger climate classification. Hydrology and earth system sciences discussions 4:439-473. 
Peres LF, Lucena AJ, Rotunno-Filho OC, França JRF (2018) The urban heat island in Rio de Janeiro, Brazil, in the last 30 years using remote sensing data. International journal of applied earth observation and geoinformation 64:104-116.

Pooley S (2020) Croc Digest: A bibliography of human-crocodile conflict research and reports. 3 ed. Simon Pooley, London, England.

Pooley S, Bhatia S, Vasava A (2021a) Rethinking the study of human-wildlife coexistence. Conservation Biology 35:784-793.

Pooley S, Siroski PA, Fernandez L, Sideleau B, PonceCampos P (2021b) Human-crocodilian interactions in Latin America and the Caribbean region. Conservation Science and Practice 3:e351.

Rebouças ADC (1997) Água na região Nordeste: desperdício e escassez. Estudos avançados 11:127154.

Roberto IJ, Bittencourt PS, Muniz FL, HernándezRangel SM, Nóbrega YC, Ávila RW, Souza BC, Alvarez G, Miranda-Chumacero G, Campos Z, Farias IP (2020) Unexpected but unsurprising lineage diversity within the most widespread Neotropical crocodilian genus Caiman (Crocodylia, Alligatoridae). Systematics and Biodiversity 18:377395.

Rodriguez D, Cedeño-Vázquez JR, Forstner MR, Densmore III LD (2008) Hybridization between Crocodylus acutus and Crocodylus moreletii in the Yucatan Peninsula: II. Evidence from microsatellites. Journal of Experimental Zoology Part A: Ecological Genetics and Physiology 309:674-686.

Silva JMC, Prasad S, Diniz-Filho JAF (2017) The impact of deforestation, urbanization, public investments, and agriculture on human welfare in the Brazilian Amazonia. Land Use Policy 65:135-142.

Silva AMC, Cunha MCC, Lopes DV (2019) Qualidade da água como reflexo de atividades antrópicas em bacias hidrográficas do Nordeste, Brasil. Geosul 34: 102-123.

Siroski P, Bassetti LAB, Piña C, Larriera A (2020) Caiman latirostris (in IUCN Red List of Threatened Species 2020). IUCN e.T46585A3009813. [https://dx.doi.org/10. 2305/IUCN . UK . 2020-3.RLTS . T46585A3009813.en] Accessed 18 June 2021.
Somaweera R, Nifong J, Rosenblatt A, Brien ML, Combrink X, Elsey RM, Gordon G, Magnusson W, Mazzotti F, Pearcy A, Platt S, Shirley M, Tellez M, Van der Ploeg J, Webb G, Whitaker R, Webber B (2020) The ecological importance of crocodylians: towards evidence-based justification for their conservation. Biological Reviews 95:936-959.

SOSMA (2021) SOS Mata Atlântica. [https:// www. sosma.org.br/conheca/mata-atlantica/] Accessed in 13 july 2021.

Souza AG (2001) Favelas, invasões e ocupações coletivas nas grandes cidades brasileiras-(Re) Qualificando a questão para Salvador-BA. Cadernos Metrópole 5: 63-89.

Teacher AG, Griffiths DJ, Hodgson DJ, Inger R (2013) Smartphones in ecology and evolution: A guide for the app-rehensive. Ecology and Evolution 3:5268-5278.

Teixeira CP, Passos L, Goulart VD, Hirsch A, Rodrigues M, Young RJ (2016) Evaluating patterns of human-reptile conflicts in an urban environment. Wildlife research 42:570-578.

Thorbjarnarson JB (2010) Black caiman Melanosuchus niger. In: Manolis SC, Stevenson $\mathrm{C}$ (eds) Crocodiles. Status survey and conservation action plan. 3 ed. Crocodile SpecialistGroup, Darwin, pp. 29-39.

Vale CA, Prezoto F (2019) Fauna Urbana: quem vive aqui? CES Revista 33:119-146.

Verdade LM (2004) A exploração da fauna silvestre: jacarés, sistema e recursos humanos. Biota Neotropica 4:1-12.

Verdade LM, Piña CI (2007) O jacaré-de-papoamarelo (Caiman latirostris Daudin, 1802). Herpetologia no Brasil 2:295-307.

Zellmer AJ, Wood EM, Surasinghe T, Putman BJ, Pauly GB, Magle SB, Lewis JS, Kay CAM, Fidino M (2020) What can we learn from wildlife sightings during the COVID-19 global shutdown? Ecosphere 11:e03215.

Received: 05 August 2021 Accepted: 03 November 2021 Published: 15 December 2021 


\section{Additional Files}

Add File 1. Number of records of journalistic news on caimans in urban areas in different regions and states of Brazil between January 2016 and May 2021.

\begin{tabular}{|c|c|c|c|}
\hline Region & State & City & Number of records \\
\hline \multirow{23}{*}{ Midwest } & $\mathrm{DF}$ & Brasília & 7 \\
\hline & \multirow{7}{*}{ GO } & Goiânia & 1 \\
\hline & & Itaberaí & 1 \\
\hline & & Itumbiara & 1 \\
\hline & & Nova Gama & 1 \\
\hline & & Porangatu & 2 \\
\hline & & Rio Verde & 1 \\
\hline & & São Miguel do Araguaia & 1 \\
\hline & \multirow{11}{*}{ MS } & Aquidauana & 2 \\
\hline & & Bataguassu & 2 \\
\hline & & Campo Grande & 4 \\
\hline & & Corumbá & 2 \\
\hline & & Coxim & 1 \\
\hline & & Ladário & 3 \\
\hline & & Miranda & 2 \\
\hline & & Nova Alvorada do Sul & 1 \\
\hline & & Paranaíba & 1 \\
\hline & & Porto Murtinho & 1 \\
\hline & & Três Lagoas & 9 \\
\hline & \multirow{4}{*}{$\mathrm{MT}$} & Alta Floresta & 3 \\
\hline & & Cana Brava do Norte & 1 \\
\hline & & Cuiabá & 6 \\
\hline & & Sinop & 1 \\
\hline \multirow{9}{*}{ North } & \multirow{3}{*}{$\mathrm{AC}$} & Cruzeiro do Sul & 2 \\
\hline & & Rio Branco & 4 \\
\hline & & Sena Madureira & 3 \\
\hline & \multirow{5}{*}{$\mathrm{AM}$} & Careiro da Várzea & 1 \\
\hline & & Iranduba & 1 \\
\hline & & Itacoatiara & 2 \\
\hline & & Manaus & 28 \\
\hline & & Tapauá & 1 \\
\hline & $\mathrm{AP}$ & Macapá & 5 \\
\hline
\end{tabular}




\begin{tabular}{|c|c|c|c|}
\hline & & Belém & 9 \\
\hline & & Breves & 1 \\
\hline & & Itaituba & 1 \\
\hline & $\mathrm{PA}$ & Marabá & 3 \\
\hline & & Marituba & 1 \\
\hline & & Novo Progresso & 1 \\
\hline & & Santarém & 4 \\
\hline & $\mathrm{BO}$ & Monte Negro & 1 \\
\hline & 100 & Porto Velho & 3 \\
\hline & & Boa Vista & 5 \\
\hline & KR & Rorainópolis & 1 \\
\hline & & Araguacema & 1 \\
\hline & & Araguaína & 1 \\
\hline & & Araguatins & 1 \\
\hline North & & Cariri & 1 \\
\hline & & Colinas & 1 \\
\hline & & Formoso do Araguaia & 2 \\
\hline & & Guaraí & 1 \\
\hline & & Gurupi & 3 \\
\hline & $\mathrm{TO}$ & Lagoa da Confusão & 2 \\
\hline & & Marianópolis & 1 \\
\hline & & Miracema & 1 \\
\hline & & Miranorte & 1 \\
\hline & & Palmas & 3 \\
\hline & & Peixe & 1 \\
\hline & & Porto Nacional & 1 \\
\hline & & Silvanópolis & 1 \\
\hline & & Arapiraca & 1 \\
\hline & & Branquinha & 1 \\
\hline & & Coruripe & 2 \\
\hline & & Maceió & 3 \\
\hline & $\mathrm{AL}$ & Marechal Deodoro & 7 \\
\hline & & Palmeira dos Índios & 1 \\
\hline & & Pilar & 1 \\
\hline & & Porto de Pedras & 1 \\
\hline Northeast & & Santana do Mundaú & 1 \\
\hline & & Canudos & 1 \\
\hline & & Eunápolis & 1 \\
\hline & & Feira de Santana & 1 \\
\hline
\end{tabular}




\begin{tabular}{|c|c|c|c|}
\hline & & Itaberaba & 1 \\
\hline & & Itamaraju & 1 \\
\hline & & Juazeiro & 1 \\
\hline & & Porto Seguro & 1 \\
\hline & & Salvador & 14 \\
\hline & & Valença & 1 \\
\hline & & Caucaia & 2 \\
\hline & & Fortaleza & 1 \\
\hline & & Granja & 1 \\
\hline & $\mathrm{CE}$ & Horizonte & 1 \\
\hline & & Ipueiras & 1 \\
\hline & & Paracuru & 1 \\
\hline & MA & São Luís & 2 \\
\hline & & Cabedelo & 1 \\
\hline & & Campina Grande & 1 \\
\hline & $\mathrm{PB}$ & João Pessoa & 8 \\
\hline & FD & Lagoa Seca & 1 \\
\hline & & Picos & 1 \\
\hline & & Pitimbu & 1 \\
\hline \multirow[t]{21}{*}{ Northeast } & & São Bento & 1 \\
\hline & & Cabo de Santo Agostinho & 2 \\
\hline & & Camaragibe & 1 \\
\hline & & Gameleira & 1 \\
\hline & & Igarassu & 1 \\
\hline & $\mathrm{PE}$ & Jaboatão dos Guararapes & 3 \\
\hline & & Olinda & 4 \\
\hline & & Paulista & 8 \\
\hline & & Petrolina & 2 \\
\hline & & Recife & 14 \\
\hline & & Esperantina & 1 \\
\hline & & Parnaíba & 1 \\
\hline & PI & Picos & 4 \\
\hline & & Piripiri & 1 \\
\hline & & Teresina & 4 \\
\hline & & Ceará-Mirim & 1 \\
\hline & $\mathrm{RN}$ & Natal & 2 \\
\hline & & São Gonçalo do Amarante & 1 \\
\hline & SE & Aracajú & 2 \\
\hline & & Matinhos & 1 \\
\hline & & Paranaguá & 1 \\
\hline
\end{tabular}


Paranavaí

Pontal do Paraná

Umuarama

Arroio do Sal

Gravataí

RS

Guaíba

Osório

Rio Grande

Santa Maria

Capivari de Baixo

Concordia

Florianópolis

South

Garuva

$\mathrm{SC}$

Indaial

Jaguaruna

Joinville

Laguna

Tijucas

Guarapari

ES Laranja da Terra

Serra

Vitória

Araçuaí

Belo Horizonte

Bom Despacho

Carmo do Rio Claro

Governador Valadares

MG Janaúba

Lagoa Santa

$$
\text { Luz }
$$

Montes Claros

Pirapora

Uberaba

Barra do Piraí

Campos dos Goytacazes

Iguaba Grande

$$
\text { Macaé }
$$

Maricá

$$
\text { Niterói }
$$

Paraíba do Sul 


\begin{tabular}{|c|c|c|c|}
\hline & & Paraty & 1 \\
\hline & & Porto Real & 1 \\
\hline & & Rio de Janeiro & 21 \\
\hline & & São Gonçalo & 2 \\
\hline & & São José do Imbassaí & 1 \\
\hline & & Vassouras & 3 \\
\hline & & Volta Redonda & 1 \\
\hline & & Águas de São Pedro & 1 \\
\hline & & Araras & 1 \\
\hline & & Bertioga & 1 \\
\hline & & Brejo Alegre & 1 \\
\hline & & Caçapava & 1 \\
\hline & & Cananeia & 1 \\
\hline & & Cananéia & 4 \\
\hline & & Charqueada & 2 \\
\hline & & Guaratinguetá & 1 \\
\hline Southoret & & Holambra & 1 \\
\hline Southeast & & Hortolândia & 1 \\
\hline & & Itapetininga & 1 \\
\hline & & Itapira & 1 \\
\hline & & Jardinópolis & 1 \\
\hline & & Limeira & 1 \\
\hline & $G D$ & Marília & 1 \\
\hline & SP & Martinópolis & 1 \\
\hline & & Nova Lusitânia & 1 \\
\hline & & Osasco & 1 \\
\hline & & Paulínia & 2 \\
\hline & & Paulistânia & 1 \\
\hline & & Pereira Barreto & 1 \\
\hline & & Piracicaba & 1 \\
\hline & & Presidente Venceslau & 1 \\
\hline & & Regente Feijó & 1 \\
\hline & & Ribeirão Preto & 1 \\
\hline & & Santos & 5 \\
\hline & & São Carlos & 1 \\
\hline & & Sorocaba & 1 \\
\hline & & Tupã & 1 \\
\hline
\end{tabular}

